\title{
Resources
}

Pacific Literature Searches in the Internet Age STUART DAWRS

The Contemporary Pacific, Volume 28, Number 2, 4I I-426

(C) 2016 by University of Hawai' $i$ Press 


\section{Pacific Literature Searches \\ in the Internet Age}

Stuart Dawrs

The universe (which others call the Library) is composed of an indefinite and perhaps infinite number of hexagonal galleries, with vast air shafts between, surrounded by very low railings. From any of the hexagons one can see, interminably, the upper and lower floors. The distribution of the galleries is invariable. Twenty shelves, five long shelves per side, cover all the sides except two; their height, which is the distance from floor to ceiling, scarcely exceeds that of a normal bookcase. One of the free sides leads to a narrow hallway which opens onto another gallery, identical to the first and to all the rest.... Also through here passes a spiral stairway, which sinks abysmally and soars upwards to remote distances. In the hallway there is a mirror which faithfully duplicates all appearances. Men usually infer from this mirror that the Library is not infinite (if it really were, why this illusory duplication?); I prefer to dream that its polished surfaces represent and promise the infinite ...

- Jorge Luis Borges, "The Library of Babel”

I recently had the opportunity to revisit Jorge Luis Borges's short story "The Library of Babel," which I had first read in the mid-r980s as a teenage undergraduate. I liked the story back then, though I can't say that I understood it as intended by the author. In Borges's library, one finds an infinite number of books, each with the same number of pages, lines of text per page, and (more or less) characters per line. There is no discernable arrangement in the library, and the vast majority of the texts appear to be complete gibberish, though-so the library's adherents believesomewhere in that infinity of books there is also captured every worthy or intelligible thought.

The Contemporary Pacific, Volume 28, Number 2, 4I 2-426

(C) 2016 by University of Hawai' $i$ Press

$4 \mathrm{I} 2$ 
Thirty years on and, still to my surprise, I find myself a librarian. My recent return to Borges's library was prompted by a classroom meeting at the University of Hawai'i (UH) at Mānoa with a group of graduate students, each of whom was in the process of producing a literature review as part of their requirements for a master's in Pacific Islands studies. "The Library of Babel" was an assigned reading for the class, and while preparing for our meeting I did what most anyone would do . . . I Googled. Wikipedia provided a decent summary and analysis of the story, including the assertion that it "lends itself to the philosophical idea proposed by Immanuel Kant, that our mind helps to structure our experience of reality" (Wikipedia 20I 5a). ${ }^{1}$ Fair enough: The universe of knowledge, and indeed what is knowable, is mutable-what makes sense to you may be gibberish to me; what is important to me may be wholly unnecessary to you.

In this sense, Borges's story speaks to the act of creating a literature review: The collection of knowledge that each of us assembles over the course of our lives, academic and otherwise, is indeed unique to usnot just our personal libraries of physical books on shelves or our digital library of PDF'd journal articles and bookmarked web pages, but also our individual libraries of experience and education and memory. ${ }^{2}$ The way that Epeli Hau'ofa or Greg Denning or Steven Winduo or even (now that he's been mentioned) Jorge Luis Borges fits into your library may be unfathomable to me. Likewise, to you, my arrangement may remain inscrutable and opaque. Hence the need for a literature review in the first place - to situate your research within that broad universe, to compile and occupy your own library. And just as no two collections of knowledge are the same, so it's also true that no two literature reviews-either in the process of their creation or in their final content-will be exactly the same.

On another level, Borges unintentionally prefigured what it means to live in the digital age. "The Library of Babel" was written in Argentina in I94I. Viewing it through a twenty-first-century, English-reading lens should cause literary scholars to cringe, but parallels with the Internet are nearly impossible to avoid. Many of us now have $24 / 7$ access to a vast and ever-growing library of information that has no beginning or end. We enter wherever and whenever we please-choose our hexagon if you will-and start to wander. Or, put another way, we begin each voyage by dropping out of the sky and into the middle of an ocean of unknown boundaries, from there to set sail for points beyond the horizon. It seems hardly coincidental to those familiar with life in the Pacific that words like 
"navigation" and "wayfinding" are part of our modern Internet searching lexicon. ${ }^{3}$

At times, as when one is seeking a quick and vaguely sourced synopsis of a short story by an Argentinian author, the Internet offers up its treasures without a fight. At other times, the process is akin to identifying a specific drop of water in the deep blue sea. For example, the library I work in holds a copy of Abel Du Petit-Thouars's Voyage autour du monde sur la frégate la Vénus (I 840 ). It also holds Quelques mots sur l'histoire de Tahiti en réponse a la presse de Papeete (I 888), the first-known publication by Teuira Henry, who is better known to the anglophone world for her Ancient Tahiti (1928). There is, potentially, a historical and intellectual line that can be drawn between Du Petit-Thouars's Voyage, which in part documents the arrival of French military power in Tahiti, and Henry's Quelques mots, an anticolonial editorial published in Papeete forty-eight years later. But this kind of conceptual arrangement of information is not something that Internet search engines are good at negotiating. Unless you already know of the existence of both titles and search specifically for them, you won't find these items on the same page of a Google search result—or, for that matter, sitting side by side on a library shelf. But with the right search query used in a library's online catalog, you could very well see them grouped together on your computer screen even if you did not previously know of either's existence-or even if you (comme moi) do not speak or read French.

In Doing a Literature Review: Releasing the Social Science Research Imagination, Chris Hart wrote, "Many reviews, in fact, are only thinly disguised annotated bibliographies. Quality means appropriate breadth and depth, rigour and consistency, clarity and brevity, and effective analysis and synthesis; in other words, the use of the ideas in the literature to justify the particular approach to the topic, the selection of methods, and the demonstration that this research contributes something new" (I998, I). Hart and other authors (see, eg, O'Leary 20I4; Galvan 2009) have attempted far more comprehensive overviews than would be possible here. The purpose of this essay is thus not to define literature reviews so much as to explore one particular aspect of the process: the literature search and how librarians and libraries fit into that process, particularly in the age of the Internet. My goal here is to address that specific portion of the review that, to use Hart's terms, helps to create breadth and depth, rigor and consistency, clarity and brevity, and not so much (not at all, really) about the portion that deals with the analysis and synthesis of texts into 
one's personal research project. It is intended, then, less as a step-by-step "how to" than as a guide to conceptualizing the search process as a whole, particularly as that process plays out within the multidisciplinary field of Pacific Islands studies.

Even so, there are some general steps to be aware of. To that end, at UH Mānoa, we recently developed both an online research guide and a research checklist; a modified version of the latter is included here as appendix I. ${ }^{4}$ The primary purpose of this checklist is to make sure that researchers are aware of certain specific resources and search techniques, so that they may either make use of them or consciously rule them out as irrelevant. What follows is largely gleaned from presentation notes I've made over the years when preparing to discuss literature searching with graduate students in Pacific Islands studies; it takes the checklist as a starting point.

\section{Step i: Formulating Your Research Question and Situating It within an Academic Field}

Let it suffice now for me to repeat the classic dictum: The Library is a sphere whose exact center is any one of its hexagons and whose circumference is inaccessible. (Borges 1962, 52)

Though academic librarians often have second degrees or their own subject specializations and research interests, in many cases they enter into the literature review process a bit downstream: Generally speaking, a fair portion of the work of formulating a research question initially takes place outside of the library. Some of it draws on a student's personal experience and previous academic pursuits; much of it is solidified in consultation with faculty and academic advisors. In my experience, this first step in the process is a fine place to be using the Internet as an exploratory tool. For instance, if you're planning to base your academic career on the hypothesis that the Pacific was settled by random drifting, you might want to Google that. I'm being facetious, but only just so: If something has been done well, done wrong, or done to death, you will often discover that fairly quickly on the Internet.

But there is just as much that the Internet will not provide. As a master's level researcher, even if you are purposely working to decolonize, reenvision, cut across the grain of, or altogether discard a previous body of research, you will still need to demonstrate your knowledge of its exis- 
tence. Once you have a research question in mind, you will need to start thinking about where within the academic milieu you are going to situate your work. Anthropology? Cultural Studies? History? This grounding may shift over time, and much of it is again the result of negotiations between you and your academic advisor, in consultation with the various faculty who are at your disposal. While librarians aren't always able to give advice on how you should situate your work, we do enter the process in other ways. While formulating a research topic, it is particularly useful to explore what has previously been written in the form of dissertations and theses. Not only are these works the foundation of future scholarly research-and therefore an essential component to a solid literature review-but in the case of an interdisciplinary field like Pacific Islands studies they can also provide insight into where and how a research project might be situated within the larger academic terrain. And, of course, those who preceded you had to create their own literature reviews, which can be an invaluable means of discovering new works and paths of inquiry.

Dissertations and theses are increasingly available online (see Dawrs 2OI2), but it's never a bad idea to consult with a librarian during the early process of tracking down relevant works, particularly if you're embarking on graduate-level research for the first time and are unfamiliar with the sometimes arcane language used in library catalogs and academic databases. Often, what makes for a good research thesis question doesn't necessarily translate into library-ese. Knowing when to use "natural language" - that is, the type of keyword searching that one uses on the Internet-and "controlled vocabulary" (ie, Library of Congress subject headings [LCSHs] or Boolean search strings) can be the difference between finding what you need and coming up empty. No one is born with this skill, and in my opinion no researcher should be expected to have at the front of their mind all of the variables that go into searching for material scattered throughout the Library of Babel. This is what academic librarians are for: Our contribution to the literature search process includes helping you to first assess your information needs and then work your research question into search queries that will meet those needs.

\section{Step 2: The Universe versus Your Private Hexagon}

When it was proclaimed that the Library contained all books, the first impression was one of extravagant happiness. (Borges I962, 54) 
I work in the Library of Babel ... or at least, in a reasonable facsimile. The Pacific Collection at UH Mānoa's Hamilton Library has a comprehensive collection development policy: We collect material in all languages, all subject areas, all time periods, all formats, all reading levels, published or unpublished; we collect photographs, diaries, and letters; audio and video; posters, pamphlets, and numerous other forms of ephemera-even the occasional T-shirt, medallion, and bumper sticker. So long as the item in question is related in one way or another to the Pacific Islands region, and can in one way or another be cataloged and housed on a library shelf, we attempt to acquire, permanently archive, and make it available. ${ }^{5}$ In addition to the physical materials we collect and preserve, we also actively produce new versions of material via a digitization program that places selected copies of print materials into two online repositories-ScholarSpace and eVols-where they are in turn made freely available on the Internet. More than 17,000 photographs and drawings have also to date been digitized and are freely available via a total of eleven online photo collections. More recently, we have begun to collect and archive selected segments of the Pacific-related Internet (for more on this work, see Kleiber 20I4). With the demise of numerous government printing offices throughout the Pacific and the general rise of desktop publishing, we also regularly gather and attempt to archive "born-digital" material that may or may not ever be released in print form.

I go on about all of this at some length by way of illustrating the challenges faced by graduate-level students as they undertake research in Pacific Islands studies. The library I work in is just one of several worldwide that either focus on the Pacific region or hold Pacific-related content; surrounding these brick-and-mortar institutions (with their attendant digital repositories and their subscriptions to vast arrays of paid databases), there is the Internet. So not only are students of Pacific Islands studies working in a field that is interdisciplinary-and so do not have the luxury of a predetermined academic discipline to situate themselves within—but they are also dealing with a universe of information that is ever expanding.

In order to make some sense out of all of this, it is important to establish as early as possible where in this vast universe you will be planting your own tree of knowledge (mixed metaphor, I know-I'm no Borges). Initially, this means scoping out a research topic and situating it within an academic field of study. In order to keep from losing your way (or your mind) in the literature search process, as a next step it's helpful to plot out in advance where you will be looking. What physical repositories 
may hold material on your topic? What databases are best used? What corners of the Internet might hold information? These are all questions that a librarian is well placed to answer. Taking the time to map out where you're going to search and in what order, and spending a bit more time thinking about keywords and search terminology before you dive in, will save you time in the long run.

Table I includes links to two resources that can help with the searchlanguage portion of a literature review: "Useful Subject Headings for Browsing Voyager Catalog" is a brief list of some of the more heavily used, Pacific-specific Library of Congress subject headings; "Library of Congress Subject Headings for the Pacific Islands" is a much more comprehensive listing of Pacific-related LCsHs. For a more in-depth discussion of how one might combine natural language with LCSH and Boolean operators to do a literature search on a specific topic, see D Keali'i MacKenzie's "Rules for the Game: Resources for Researching Pacific Islands Sport" (20I4).

\section{SteP 3: Diving IN-Spear versus Net}

As was natural, this inordinate hope was followed by an excessive depression. (Borges I962, 55)

In the digital age, we've been conditioned to believe that casting a wide net (using the [Inter]net) is the way to all knowledge. Throw it out there (via Google or Bing or Yahoo or What-Have-You), haul it in, and sift through page upon page of information that has been presorted by an algorithm of unknown parameters. In our day-to-day world, more often than not this works perfectly fine: In the last two weeks, I've fished up a diagnosis for my daughter's appendicitis and instructions on how to fix the family espresso machine. So, yes, I'm a big fan. But when it comes to academic research, I like to use the analogy of spearfishing versus 'net fishing. If you wade into unfamiliar waters and throw a net, you will, with a little skill or luck (or both), haul in a fair number of fish . . . but if you don't know what these fish are or how to prepare them to eat or even which ones are edible, you'll end up wasting a fair amount of time simply staring at a net full of flopping fish. Better to start with a spear and be more selective.

This analogy tends to unravel if you think about it too closely, so let's skip to the point: Given the huge amount of information at our disposal, I find that it is often best to start as narrowly as possible and then broaden 
Table I Publicly Available Online Resources Mentioned

\begin{tabular}{|c|c|c|}
\hline Website & Host & URL \\
\hline Articles \& More & $\begin{array}{l}\text { University of Auckland } \\
\text { Library }\end{array}$ & http://www.library.auckland.ac.nz \\
\hline $\begin{array}{l}\text { The British Newspaper } \\
\text { Archive }\end{array}$ & $\begin{array}{l}\text { Findmypast Newspaper } \\
\text { Archive Ltd }\end{array}$ & http://www.britishnewspaperarchive.co.uk/ \\
\hline Chronicling America & Library of Congress & http://chroniclingamerica.loc.gov \\
\hline $\begin{array}{l}\text { Digital \& Digitized Collec- } \\
\text { tions (UH Mānoa Hamilton } \\
\text { Library online photo } \\
\text { collections) }\end{array}$ & uH Mānoa Hamilton Library & $\begin{array}{l}\text { http://library.manoa.hawaii.edu/research/ } \\
\text { digicoll.php }\end{array}$ \\
\hline eVols & uH Mānoa Hamilton Library & http://evols.library.manoa.hawaii.edu \\
\hline Google Books & Google & http://books.google.com \\
\hline Google Scholar & Google & https://scholar.google.com \\
\hline $\begin{array}{l}\text { Hawaii Pacific Journal } \\
\text { Index }\end{array}$ & uH Mānoa Hamilton Library & http://hpji.lib.hawaii.edu \\
\hline LexisNexis Academic & LexisNexis & $\begin{array}{l}\text { http://www.lexisnexis.com/hottopics/ } \\
\text { lnacademic/? }\end{array}$ \\
\hline $\begin{array}{l}\text { Library of Congress } \\
\text { Subject Headings for the } \\
\text { Pacific Islands }\end{array}$ & uH Mānoa Hamilton Library & $\begin{array}{l}\text { http://scholarspace.manoa.hawaii.edu/ } \\
\text { handle/10125/38703 }\end{array}$ \\
\hline OneSearch & uH Mānoa Hamilton Library & http://library.manoa.hawaii.edu \\
\hline Pacific Islands Report & $\begin{array}{l}\text { Pacific Islands Development } \\
\text { Program, East-West Center }\end{array}$ & http://pidp.eastwestcenter.org/pireport/ \\
\hline Papers Past & $\begin{array}{l}\text { National Library of } \\
\text { New Zealand }\end{array}$ & $\begin{array}{l}\text { http://paperspast.natlib.govt.nz/cgi-bin/ } \\
\text { paperspast }\end{array}$ \\
\hline ProQuest & ProQuest & $\begin{array}{l}\text { http://www.proquest.com/products-services/ } \\
\text { dissertations/Find-a-Dissertation.html }\end{array}$ \\
\hline $\begin{array}{l}\text { Researching Oceania: } \\
\text { Creative and Conven- } \\
\text { tional Methods of Inquiry }\end{array}$ & uH Mānoa Hamilton Library & $\begin{array}{l}\text { http://guides.library.manoa.hawaii.edu/ } \\
\text { PACS603 }\end{array}$ \\
\hline ScholarSpace & uH Mānoa Hamilton Library & http://scholarspace.manoa.hawaii.edu \\
\hline SuperSearch & $\begin{array}{l}\text { The Australian National } \\
\text { University }\end{array}$ & $\begin{array}{l}\text { http://anulib.anu.edu.au/find-access/search } \\
\text {-help/supersearch }\end{array}$ \\
\hline Selected Databases & uH Mānoa Hamilton Library & $\begin{array}{l}\text { http://library.manoa.hawaii.edu/ } \\
\text { departments/hp/pacific/databases.php }\end{array}$ \\
\hline Trove & National Library of Australia & http://trove.nla.gov.au/ \\
\hline $\begin{array}{l}\text { Useful Subject Headings for } \\
\text { Browsing Voyager Catalog }\end{array}$ & uH Mānoa Hamilton Library & $\begin{array}{l}\text { http://scholarspace.manoa.hawaii.edu/ } \\
\text { handle/10125/38705 }\end{array}$ \\
\hline Voyager Online Catalog & uH Mānoa Hamilton Library & $\begin{array}{l}\text { https://uhmanoa.lib.hawaii.edu/vwebv/ } \\
\text { searchBasic?sk=manoa }\end{array}$ \\
\hline WorldCat & $\begin{array}{l}\text { Online Computer Library } \\
\text { Center, Inc }\end{array}$ & https://www.worldcat.org \\
\hline
\end{tabular}


searches outward, rather than vice versa. In the case of Pacific Islands studies at UH Mānoa, because our Pacific Collection is generally considered to be one of the largest of its kind, it makes sense to begin the search in the library's online catalog, Voyager, and then broaden out from there: to the online catalogs of other institutions that support similar research; to the Hawaii Pacific Journal Index (an open-access database that provides table-of-contents level indexing to approximately I 30 Hawai $i$ - and Pacific-specific journals, magazines, and newspapers); ${ }^{6}$ then to databases that are particular to the academic field in which a specific research question is situated; then to databases that are broader or more general in their coverage; and ultimately back onto the Internet. This same strategy applies no matter where you are situated: Start with what is readily available at your home institution, then broaden out from there. While it may seem counterintuitive to narrow your searches from the start, if you go in with the idea that you will eventually be searching far and wide, by the time you do get to those broad-level searches, you will already easily recognize (and quickly rule out) most of what you haul in.

\section{Step 4: The Internet, Our Difficult Friend}

Man, the imperfect librarian, may be the product of chance or of malevolent demiurgi; the universe, with its elegant endowment of shelves, of enigmatical volumes, of inexhaustible stairways for the traveler and latrines for the seated librarian, can only be the work of a god. (Borges 1962, 52)

While the process of literature searching might be likened to spearfishing, the overall process of creating a literature review could be envisioned as taking the shape of an hourglass. At the top of the glass are the early steps in the process: the work of formulating a research question and situating it within an academic discipline. At the bottom of the glass are the final steps of the process, where the literature review is largely complete and you are ready to move on to the original research that will define your contribution to the field. The middle, narrow portion of the glass is the area that makes up the literature search process.

It would be hypocritical of me to advise researchers to stay away from the Internet-I use it every day in my work. As one example, researchers often come to librarians with a partial citation to a work that has been recommended to them. Sometimes they will have an author's name but no title; sometimes they will have the title of a journal article but not the journal in which it was published. There are several ways to solve these 
riddles in a more controlled, library database environment, but these days I typically turn to the Internet as the first, faster step. Scholars who are attached to an academic institution almost invariably post some form of curriculum vitae (CV) online, including a bibliography of their published work. Often, these bibliographies will include links to open-access versions of the desired publication, but even when they don't, they (usually) include the complete citation information necessary to return to a library's databases and track down either a print or electronic copy. And, like the bibliographies compiled for dissertations and theses, a scholar's online $\mathrm{CV}$ can be an area to mine for additional resources.

What's more, many academic libraries now employ search tools that to a certain extent emulate the Internet experience. The University of Hawai'i has "OneSearch," the University of Auckland has "Articles \& More," the Australian National University has "SuperSearch" . . these and similar tools at other university libraries allow users to simultaneously search their home library's online catalog, selected subscription databases, and freely available Internet-based resources. For most undergraduates, this type of one-stop search provides more than enough relevant material. However, for graduate-level research, it's important to understand that few if any of these types of aggregate-search tools look through everything at once (UH's OneSearch certainly does not), and so again ... see steps I through 3 above.

Another challenge to using these types of search aggregators is that, much like the Internet, it's not always clear what (or how) they are searching. For example, uH Mānoa's OneSearch includes our library's digital repositories, eVols and ScholarSpace, among the several databases it searches-but it only searches specific strings of the metadata that are used to describe any given item within these repositories, and not the full text of all the material in the repositories. On the other hand, if you search within the digital repositories themselves (or even using a tool like Google Scholar), you do have the ability to search full text. So if, say, you were to use a natural-language search to look for works that cite the Papua New Guinean novelist and poet Russell Soaba, you would get a different set of results in each of these three resources (and these results would also be displayed in very different ways). The point of this example is twofold: (I) Advanced-level researchers cannot simply rely on a single online resource-whether it be the controlled environment of a library search engine or the roiling sea of the Internet-to give them all that they seek; and (2) no researcher in his or her right mind should be expected to 
keep straight all the peculiarities of searching within individual databases, let alone also keep track of the relationship between these databases and the Internet. This is another role of academic librarians in the research process.

In my own experience, the Internet is most effective (and in some cases essential) when used at the top and bottom ends of the hourglass: during the process of conceptualizing a research question and-in some cases, at least-during the process of conducting original research. This because a great deal of primary source material, from governmental statistics to YouTube videos, is now exclusively on the Internet. There are, of course, exceptions to any rule. Because it searches the full text of numerous books (not all books, but many books), Google Books can be a useful add-on when searching in library catalogs as part of the literature search process. And on the opposite end, there is still a huge wealth of primary source material that is not on the Internet and is absolutely essential to conducting original research on certain Pacific-related topics. Examples from the library I work in include things like the Album of Photographs of Nauru, circa I9I9-I920; the Archive of Letters: James Michener and Mari Michener to Leonard and Sylvia Lyons; the Interviews with Paramount Talking High Chief Alofipō, September 21, I974; and a host of other manuscript, archival, or photograph collections that can only be found in one place in the world ... and it's not the Internet.

Long story short: The process of creating a literature review can be daunting. This is to be expected for any new research project. As time goes on and the outlines of the project become clearer, so too the form of the review and the steps necessary to find what you are looking for will also become clearer. Just as searching the Internet has become second nature for most of us these days, the process of searching within library databases also becomes easier with time. In the meantime, the simplest advice of all: Ask a librarian.

\section{Notes}

I To its credit, I note that Wikipedia itself cautions against using Wikipedia as a valid source in academic research and publishing (Wikipedia $2015 \mathrm{~b}$ ). Hopefully, the point of my devil-may-care usage here will be apparent shortly.

2 I owe these thoughts on the uniqueness of personal libraries entirely to $\mathrm{Dr}$ Alexander Mawyer, who raised this idea much more eloquently than I have as 
part of an extemporaneous discussion during the classroom meeting that is referenced at the outset of this article. Furthermore, it was Dr Mawyer who assigned "The Library of Babel" to his students, and so I also owe him a debt of gratitude for reintroducing me to this work.

3 According to tech writer Peter Morville, the term "wayfinding" as it relates to the Internet stems from I96os-era architectural theory, though he does also acknowledge the relationship to Pacific voyaging and wayfinding traditions (Morville 2005).

4 The URL for the online research guide is listed in table I, along with all publicly accessible resources mentioned in this article.

5 A main exception to this policy is that we do not collect artifacts or threedimensional works of art, these being largely the purview of museums.

6 For more on the Hawaii Pacific Journal Index and how to use it, see Peacock I993 and Dawrs 20 II.

\section{References}

Borges, Jorge Luis

I962 The Library of Babel. In Labyrinths: Selected Stories and Other Writings, edited by Donald A Yates and James E Irby, 5I-58. New York: New Directions.

Dawrs, Stuart

20I I Uнм Hawaii Pacific Journal Index: An Unsung Resource. Pacific News from Mānoa 2 (April-June): 3-4.

2012 Virtually There: Open Access and the Online Growth of Pacific Dissertations and Theses. The Contemporary Pacific 24:348-357.

Galvan, Jose L

2009 Writing Literature Reviews: A Guide for Students of the Social and Behavioral Sciences. Fourth edition. Glendale, cA: Pyrczak Publishing.

Hart, Chris

I998 Doing a Literature Review: Releasing the Social Science Research Imagination. London: Sage Publications.

Kleiber, Eleanor

20I4 Gathering the 'Net: Efforts and Challenges in Archiving Pacific Websites. The Contemporary Pacific 26:1 58-166

MacKenzie, D Keali'i

20I4 Rules of the Game: Resources for Researching Pacific Islands Sport. The Contemporary Pacific 26:447-456.

Morville, Peter

2005 A Brief History of Wayfinding. In Ambient Findability: What We 
Find Changes Who We Become, I6-42. Sebastopol, CA: O'Reilly Media, Inc.

O'Leary, Zina

2014 The Essential Guide to Doing Your Research Project. Second edition. London: Sage Publications.

Peacock, Karen M

I993 Indexing the Pacific Islands: Creating a Pacific Periodical Database. The Contemporary Pacific 5:432-435.

Wikipedia Contributors

20I5a The Library of Babel. https://en.wikipedia.org/wiki/The_Library_of _Babel [accessed 29 July 20I5]

20I5b Wikipedia: Citing Wikipedia. https://en.wikipedia.org/wiki/Wikipe dia:Citing_Wikipedia\#MLA_style [accessed 29 July 20I 5]

\section{Abstract}

The purpose of this essay is to explore one particular aspect of a master's-level literature review: the literature search. Emphasis is placed on how librarians and libraries fit into the search process, particularly in the age of the Internet. The essay is intended less as a step-by-step "how to" than as a guide to conceptualizing the search process as a whole, particularly as that process plays out within the multidisciplinary field of Pacific Islands studies.

KEYWORDS: literature review, research, resources, libraries 
Appendix I A Checklist for Pacific Islands Studies Literature Reviews

I Formulating your research question and situating it within an academic field

$\square \quad$ I have consulted with faculty within my field(s) of research.

$\square \quad$ I know what broad field(s) of academia my work is situated within, either directly or indirectly (cultural studies, anthropology, history, or so forth).

$\square \quad$ I know the genealogy of this field of study (its history as an academic discipline, the major theories and thinkers, and how those theories may have changed over time).

$\square \quad$ I know the major theories and thinkers within Pacific Islands studies that draw on this larger academic field.

2 Doing the literature search

$\square \quad$ I have met with a librarian to consult on my topic.

$\square \quad$ I have a good idea of where I need to look for materials, and in what order I want to look for them.

$\square \quad$ I have brainstormed keywords that may be useful in database research.

$\square \quad$ I have a list of potential Library of Congress subject headings (LCSHS) that may be used to help refine my searches in databases. (See table I for URLS of "Library of Congress Subject Headings for Pacific Islands" and "Useful Subject Headings for Browsing Voyager Catalog.")

$\square \quad$ I have explored the online library guide "Researching Oceania: Creative and Conventional Methods of Inquiry." (See table I for URL.)

$\square \quad$ I know what is physically and virtually available at the UH Mānoa library on my subject; I have searched (or consciously ruled out):

$\square$ Voyager Online Catalog

$\square$ Hawaii Pacific Journal Index

$\square$ Google Books

$\square$ OneSearch Mānoa

$\square$ directly within the library's digital repositories, ScholarSpace and eVols

$\square$ the library's online photo collections, via its Digital \& Digitized Collections webpage (see table I for URL)

$\square \quad$ I have explored (or consciously ruled out) other libraries and archives:

$\square$ WorldCat

$\square$ directly within other libraries' online catalogs

$\square$ Proquest Dissertations \& Theses

$\square$ within an institution's digital repository (either directly or using some combination of the resources discussed in the article "Virtually There" [Dawrs 20I2])

$\square$ Google Scholar 
$\square \quad$ I have searched (or consciously ruled out) scholarly (and popular press) publishing on my topic:

$\square$ Hawaii Pacific Journal Index

$\square$ OneSearch Mānoa

口 relevant databases (eg, UH Mānoa Library's "Selected Databases” for finding Pacific-related materials; see table I for URL)

$\square$ historical newspaper databases (eg, Chronicling America, Papers Past, Trove, British Newspaper Archive)

$\square$ modern news aggregators (eg, Pacific Islands Report, LexisNexis)

$\square \quad$ I have consulted with cultural practitioners and am aware of what exists outside of traditional academic resources concerning my topic.

$\square \quad$ I have Googled it.

$\square \quad$ I feel reasonably confident that I know the universe of information I'm working within.

3 Keeping track of your citations

$\square \quad$ I have a plan for organizing my sources (eg, Endnote, Zotero, sticky notes and index cards) 